Sains Peternakan Vol. 14 (2), September 2016: 1-11

ISSN 1693-8828

\title{
Suplementasi L-Karnitin dan Asam Lemak PUFA Terproteksi dalam Ransum Limbah Pasar Organik Terfermentasi Pengaruhnya Terhadap Komposisi Kimiawi Air Susu Kambing
}

\author{
Sudibya, A. Hanifa, E. Handayanta, A. Intansari dan R.F. Hadi \\ Program Studi Peternakan Fakultas Pertanian Universitas Sebelas Maret \\ Jl. Ir. Sutami No 36 A Surakarta
}

\begin{abstract}
ABSTRAK
Tujuan penelitian ingin mengetahui pengaruh suplementasi L-karnitin dan asam lemak PUFA terproteksi dalam ransum limbah pasar terfermentasi pengaruhnya terhadap komposisi kimiawi air susu kambing.

Materi penelitian adalah 15 ekor kambing perah Peranakan Etawah (PE) dengan umur 2-4 tahun dan bobot badan berkisar $25-55 \mathrm{~kg}$. Bahan pakan yang digunakan terdiri atas rambanan dan ransum basal (jagung kuning, bekatul, bungkil kedelai, bungkil kelapa, mineral)/L-karnitin, minyak ikan tuna serta minyak ikan lemuru.

Metode penelitian adalah eksperimental secara in vivo menggunakan Rancangan Acak Kelompok (RAK) dengan 4 perlakuan dengan 3 blok sebagai ulangan. Setiap unit blok berisi 1 ekor kambing perah periode laktasi. Perlakuannya yaitu: $\mathrm{P} 0=$ ransum kontrol, $\mathrm{P} 1=\mathrm{P} 0+50 \%$ limbah pasar terfermentasi mengganti rambanan, $\mathrm{P} 2=\mathrm{P} 1+\mathrm{L}-$ karnitin $500 \mathrm{ppm}$ dalam ransum, $\mathrm{P} 3=\mathrm{P} 1+5 \%$ sabun terproteksi berisi minyak ikan tuna 5\% dalam ransum, $\mathrm{P} 4=\mathrm{P} 1+$ sabun terproteksi berisi minyak ikan lemuru 5\% dalam ransum.

Hasil analisis variansi menunjukkan bahwa suplementasi L-karnitin dan asam lemak PUFA terproteksi hingga level 5\% dalam ransum limbah pasar organik terfermentasi berpengaruh sangat nyata $(\mathrm{P}<0,01)$ terhadap kadar kolesterol, kadar LDL dan HDL serta asam lemak omega-3 dan omega-6 pada air susu kambing perah.

Kesimpulan suplementasi L-karnitin 500 ppm dan asam lemak PUFA terproteksi hingga level 5\% dalam ransum limbah pasar organik terfermentasi mampu menurunkan kadar kolesterol air susu dari 0,482\% menjadi 0,420\% dan kadar LDL (Low Density Lipoprotein) dari 45,30 mg/dl hingga 33,13 mg/dl. Selanjutnya mampu meningkatkan kadar HDL (High Density Lipoprotein ) air susu kambing dari 54,70 mg/dl menjadi $66,87 \mathrm{mg} / \mathrm{dl}$, kadar asam lemak omega-3 dari 1,10\% menjadi 4,04\% dan kadar asam lemak omega-6 dari 1,46\% hingga 18,80\% air susu kambing.
\end{abstract}

Kata kunci: air susu kambing perah, sabun terproteksi berisi minyak ikan tuna dan minyak ikan lemuru

\section{Suplementation Protection Fatty Acid PUFA and Carnitin On The Ration Of Market Waste On Composition Of Milk Dairy Goat}

\begin{abstract}
The experiment was conducted to investigate the effect of transfer protection PUFA and L-carnitin on the ration on chemist composition of dairy milk In total, 15 female dairy goats of 2-4 year this old Peranakan Etawah (PE) with body weight of 25-55 $\mathrm{kg}$ were used in this experiment. The assay diets included a basal diet (control) based on yellow corn, rice bran, soy bean meal and coconut meal, mineral, tuna fish oil and lemuru fish oil. The method of the research was experimental in vivo using Completely Randomized Blok Design (RAK). There were 5 treatment in each treatment and 3 replication. Treatment consisted of $P 0=$ control ration, $P 1=P 0+50 \%$ market waste subtition grass on the ration, $P 2=P 1+500$ ppm L-karnitin on
\end{abstract}


the ration, $P 3=P 1+$ protection tuna fish oil $5 \%$ in the ration and $P 4=P 1+$ protection lemuru fish oil $5 \%$ in the ration. The variables measuared content composition dairy milk goat.

The results of variance analysis showed that the effect of suplementation protection PUFA in the rations on market waste contain 500 ppm L-carnitine were significantly $(P<0.01)$ of acid goats milk composition. The conclusion of this research shows that the suplementation protection PUFA in the ration contain 500 ppm L-carnitine, can decrease milk cholesterol from 0,482\% to 0,420\%, LDL from 45,30 to $33,13 \mathrm{mg} / \mathrm{dl}$. There for to increase HDL from 54,70 to $66,87 \mathrm{mg} / \mathrm{dl}$, omega-3 fatty acid from 1,10\% to 4,04\%, omega-6 fatty acid from $1,46 \%$ to 18,80 percent.

Keywords: composition dairy milk goats, L-carnitine, protection PUFA fatty acid

\section{PENDAHULUAN}

Membuat produk air susu kambing yang kaya akan asam lemak omega-3 dan 6 serta rendah kolesterol merupakan terobosan baru untuk menghasilkan produk hewani yang sehat. Produk tersebut dapat dibuat dengan memanipulasi yakni dengan transfer enzim selulase dan sabun terproteksi yang berisi ekstrak asam lemak PUFA lewat ransum limbah pasar organik yang terfermentasi yang mengandung 500 ppm L-karnitin. Selanjutnya perlu dikaji perubahan komposisinya dari produk tersebut setelah dilakukan pemasakan (susu) dengan cara uji organoleptik dan kimiawi.

Penelitian tentang produk air susu kambing yang kaya asam lemak omega-3 belum banyak diungkap, namun sebagai bahan pijakan pada daging sapi potong pernah dilakukan oleh Sudibya $d k k$. (2003) yang dilanjutkan pada tahun (2006) dan pada tahun (2007) pada ternak kambing, tahun (2009) pada daging sapi Simental, tahun (2010) pada air susu sapi perah hasilnya sangat signifikan oleh karena itu bila metode tersebut diterapkan pada kambing perah dampaknya akan sama karena masih termasuk pada ternak ruminansia.

Sumber asam lemak omega-3 banyak dijumpai pada ikan laut, utamanya ikan lemuru, ikan tuna dan ikan hiu. Ikan lemuru bila di pres akan menghasilkan minyak ikan yang banyak mengandung asam lemak omega-3 utamanya EPA (Eikosapentaenoat) $34,17 \%$ dan DHA (Dokosaheksaenoat) sebanyak $17,40 \%$ dan kandungan lemaknya 6\% serta TDN $182 \mathrm{kkal} / \mathrm{kg}$ sedang minyak ikan tuna bila di pres akan menghasilkan minyak ikan yang banyak mengandung asam lemak omega-3 utamanya EPA (Eikosapentaenoat) 33,6 hingga 44,85\% dan DHA (Dokosaheksaenoat) sebanyak 14,64\% serta mengandung lemak 5,8\% dan TDN 178 kkal/kg (Sudibya $d k k$., 2004 dan 2007). Atas dasar perbedaan kandungan tersebut perlu diteliti untuk dibandingkan. Selain sumber asam lemak tak jenuh tinggi perlu dikaji suplementasi sumber asam lemak jenuh yakni minyak kedelai.

Minyak ikan merupakan sumber lemak. Manipulasi metabolisme lemak dalam rumen ditujukan untuk menghasilkan dua partikel yang pertama mengontrol pengaruh antimikroba dari asam lemak untuk meminimkan gangguan fermentasi rumen, sehingga level lemak tertinggi dapat dimasukkan dalam pakan, kedua mengontrol biohidrogenasi untuk meningkatkan absorpsi asam lemak yang dikehendaki untuk meningkatkan kualitas nutrisi produk ternak (Chillard, 1993). Suplementasi minyak ikan dalam pakan harus dengan dosis tertentu agar tidak mengganggu aktivitas mikroorganisme rumen. Jenkins (1993) menyatakan bahwa penambahan minyak ikan dalam pakan ruminansia tidak boleh lebih dari 6-7\% dari bahan kering ransum karena akan mempengaruhi fermentasi mikroorganisme rumen.

Sudibya (1998) fungsi asam lemak omega-3 dalam menurunkan kadar kolesterol 
melalui dua cara yakni 1) merangsang ekskresi kolesterol melalui empedu dari hati ke dalam usus dan 2) merangsang katabolisme kolesterol oleh HDL ke hati kembali menjadi asam empedu dan tidak diregenerasi lagi namun dikeluarkan bersama ekskreta.

Tujuan penelitian adalah:

a. Memproduksi sabun asam lemak berbahan baku limbah ikan (minyak ikan tuna dan minyak ikan lemuru).

b. Mengurangi pengaruh negatif dari minyak terhadap proses fermentasi selulolitik mikroba rumen.

c. Memperoleh dosis optimal pemberian sabun asam lemak sehingga proses fermentasi dalam rumen masih pada kisaran normal baik secara in vitro maupun secara in vivo.

d. Memproduksi air susu kambing perah yang mengandung asam lemak linolenat, linoleat dan arakhidonat tinggi dan rendah kolesterol sebagai bahan pangan yang sehat.

e. Mengkaji tingkat kecerdasan pada anakanak sekolah dasar dengan cara mengetes tingkat IQ setelah mereka meminum air susu selama 1 bulan setiap 3 hari.

Manfaat penelitian adalah :

a. Sebagai bahan informasi dalam penyusunan ransum khususnya ransum kambing perah.

\section{MATERI DAN METODE}

Penelitian ini adalah penelitian eksperimental yang sudah dilaksanakan di Desa Gledeg, Kecamatan Karanganom, Kabupaten Klaten, Laboratorium MIPA IPB Bogor, Laboratorium Kimia UGM, Laboratorium Fakultas Teknologi Pertanian UGM serta Laboratorium Nutrisi dan Makanan Ternak Program Studi Peternakan Fakultas Pertanian UNS Surakarta. Selanjutnya penelitian dilaksanakan selama empat bulan yakni mulai bulan Juni dan berakhir bulan September 2015.

\section{Materi}

a. Limbah pasar organik dan ragi tape, Lkarnitin sebagai prekursor karnitin dan bahan baku konsentrat yang lain. Sabun asam lemak terproteksi yang berisi minyak ikan tuna dan minyak ikan lemuru.

b. Kambing Peranakan Etawah (PE) laktasi sebanyak 15 ekor dengan bobot badan 25$55 \mathrm{~kg}$ dengan produksi susunya antara 250-500 ml per hari.

c. Kandang kambing satu unit untuk 15 ekor dengan ukuran panjang $15 \mathrm{~m}$ dan lebar $8 \mathrm{~m}$ dan ransum dasar sesuai dengan perlakuan (Tabel 1 dan 2).

Tabel 1. Kandungan Zat Nutrien Pada Ransum Kambing Perah Periode Laktasi

\begin{tabular}{lccccc}
\hline Kandungan nutrient & P0 & P1 & P2 & P3 & P4 \\
\hline Protein kasar \% & 12,30 & 12,95 & 12,95 & 12,95 & 12,95 \\
TDN kkal/kg & 56,0 & 56,0 & 57,0 & 58,0 & 58,0 \\
Lemak kasar (\%) & 4,82 & 5,02 & 5,02 & 5,02 & 5,02 \\
Serat kasar (\%) & 18,90 & 18,90 & 18,90 & 18,90 & 18,90 \\
Kalsium (\%) & 2,58 & 2,58 & 2,59 & 2,58 & 2,58 \\
Phospor (\%) & 0,78 & 0,78 & 0,78 & 0,78 & 0,78 \\
Omega-3 & 0 & 0 & 0 & 2,13 & 2,13 \\
\hline
\end{tabular}


Tabel 2. Susunan Ransum Pada Kambing Perah Periode Laktasi

\begin{tabular}{|c|c|c|c|c|c|}
\hline & $\mathrm{P} 0$ & P1 & $\mathrm{P} 2$ & $\mathrm{P} 3$ & P4 \\
\hline Rambanan (Browse) & 30 & 15 & 15 & 15 & 15 \\
\hline Limbah pasar organik terfermentasi & 0 & 15 & 15 & 15 & 15 \\
\hline Bungkil kedele & 10 & 10 & 10 & 10 & 10 \\
\hline Bekatul & 31 & 31 & 31 & 31 & 31 \\
\hline Jagung kuning & 20 & 20 & 20 & 20 & 20 \\
\hline Bungkil kelapa & 7 & 7 & 7 & 7 & 7 \\
\hline Premix & 2 & 2 & 2 & 2 & 2 \\
\hline L- karnitin & 0 & 0,005 & 0,005 & 0,005 & 0,005 \\
\hline $\begin{array}{l}\text { Sabun terproteksi berisi } \\
\text { PUFA minyak ikan tuna }\end{array}$ & 0 & 0 & 0 & 5 & 0 \\
\hline $\begin{array}{l}\text { Sabun terproteksi berisi PUFA } \\
\text { minyak ikan lemuru }\end{array}$ & 0 & 0 & 0 & 0 & 5 \\
\hline
\end{tabular}

Metode

Menggunakan Rancangan Acak Kelompok (RAK) dengan 5 perlakuan dan di ulang 3 kali sebagai blok serta setiap blok berisi 1 ekor kambing PE periode laktasi. Adapun perlakauannya sebagai berikut: $\mathrm{P} 0=$ ransum kontrol (bekatul, jagung kuning, konsentrat dan mineral), $\mathrm{P} 1=\mathrm{P} 0+50 \%$ limbah pasar organik terfermentasi mengganti rambanan dalam ransum, $\mathrm{P} 2=\mathrm{P} 1+500 \mathrm{ppm}$ L-karnitin dalam ransum, $\mathrm{P} 3=\mathrm{P} 1+$ sabun PUFA terproteksi yang berisi minyak ikan tuna sebesar 5\% dalam ransum, $\mathrm{P} 4=$ P1+sabun PUFA terproteksi yang berisi minyak ikan lemuru sebesar $5 \%$ dalam ransum.

\section{Peubah yang diukur}

Kadar kolesterol air susu yang sudah dimasak dengan metode Kleiner dan Dotti (1962). Kadar LDL (Low Density Lipoprotein) dan HDL (High Density Lipoprotein) air susu yang sudah dimasak dengan metode (Assman,1982). Kadar asam lemak omega-3 dan omega- 6 air susu yang sudah dimasak dengan metode (AOAC, 1990).
Analisis Data

Data dianalisis dengan sidik ragam dan bila terdapat perbedaan dilanjutkan uji kontras orthogonal (Steel dan Torrie, 1980).

\section{Pelaksanaan Penelitian secara In Vivo}

Penelitian secara in vivo terbagi menjadi tiga tahap, meliputi tahap adaptasi, preliminary dan koleksi. Tahap adaptasi bertujuan untuk membiasakan ternak kambing perah menyesuaikan dengan kandang, lingkungan dan pakan yang akan digunakan. Hal-hal yang dilakukan pada tahap adaptasi antara lain: memberikan pakan yang akan digunakan sedikit demi sedikit namun sesering mungkin, memberikan air minum secara ad libitum. Menghentikan tahap adaptasi setelah kambing perah dapat mengkonsumsi pakan percobaan dengan baik (kurang lebih satu minggu).

Tahap preliminary bertujuan untuk menghilangkan pengaruh pakan pada periode sebelumnya. Hal-hal yang dilakukan pada periode preliminary antara lain: melakukan pengacakan pakan perlakukan pada masingmasing kelompok, melakukan penghitungan produksi susu setiap hari. Pada waktu yang sama (setiap sebelum kambing perah diberi 
pakan atau sekitar 07.00 WIB) untuk menentukan kebutuhan pakan yang harus diberikan, melakukan periode tersebut kurang lebih empat minggu.

Tahap koleksi merupakan tahap pengambilan data dari perlakuan yang diuji. Metode yang digunakan adalah koleksi total menurut Schneider dan Flatt (1975) yang dilakukan selama 7 hari dengan tahapan sebagai berikut: a) mengumpulkan dan menimbang pakan perlakuan (pemberian dan sisa) untuk menentukan konsumsi harian masing-masing kambing perah, b) mengumpulkan feses dari masing-masing kambing perah setiap hari, c) mengambil sampel feses dan pakan perlakuan (pemberian dan sisa) sebanyak 5 persen dari berat yang terkumpul setiap hari, d) menyemprot sampel feses menggunakan $5 \%$ formalin, e) mengeringkan sampel pakan dan feses ke dalam oven pada suhu $60^{\circ} \mathrm{C}$.

Tahap terakhir dilakukan penghitungan produksi susu dan diambil $25 \%$ dari jumlah kambing perah untuk dilakukan sebagai sampel yang digunakan untuk analisa kadar kolesterol, kadar lemak dan kadar asam lemak omega-3 serta angka peroksida dan bilangan TBA (Asam thiobarbiturat).

\section{HASIL DAN PEMBAHASAN}

\section{Kadar Kolesterol Air Susu Kambing}

Kadar kolesterol air susu kambing yang terendah pada perlakuan P4 yakni $0,420 \%$, sedangkan yang tertinggi pada perlakuan P0 yakni 0,482\%. Data selengkapnya dapat dilihat pada Tabel 3 . Hasil analisis statistik menunjukkan bahwa perlakuan suplementasi L-karnitin dan minyak ikan tuna dan minyak ikan lemuru terproteksi berpengaruh sangat nyata $(\mathrm{P}<0,01)$ terhadap kadar kolesterol air susu kambing. Dari uji lanjut orthogonal kontras terlihat bahwa kadar kolesterol air susu kambing pada P0, P1 dan P2 berbeda sangat nyata dengan P3 dan P4. Selanjutnya P1 dan P2 berbeda sangat nyata dengan P3 dan P4 sedangkan P3 berbeda tidak nyata dengan $\mathrm{P} 4$.

Kadar kolesterol susu kambing yang ditambah L-karnitin (P2) dapat mengalami penurunan bila dibanding pada $\mathrm{P} 0$ dan $\mathrm{P} 1$ hal ini sejalan dengan pendapat Sudibya et al. (2010) yang menyatakan bahwa suplementasi L-karnitin dapat digunakan untuk menurunkan kadar kolesterol daging sapi, hal ini sejalan dengan pendapat Owen et al. (1996) bahwa suplementasi L-karnitin berfungsi antara lain dapat menurunkan kandungan kolesterol dalam produk.

Tabel 3. Rataan kadar kolesterol, Low Density Lipoprotein ( LDL) dan High Density Lipoprotein (HDL) air susu kambing

\begin{tabular}{llllll}
\hline Peubah yang diukur & $\mathrm{P} 0$ & $\mathrm{P} 1$ & $\mathrm{P} 2$ & $\mathrm{P} 3$ & $\mathrm{P} 4$ \\
\hline Kadar kolesterol susu kambing (\%) & $0,482^{\mathrm{a}}$ & $0,470^{\mathrm{a}}$ & $0,468^{\mathrm{a}}$ & $0,424^{\mathrm{b}}$ & $0,420^{\mathrm{b}}$ \\
$\begin{array}{l}\text { Kadar LDL (Low Density Lipoprotein) air susu } \\
\text { kambing (mg/dl) }\end{array}$ & $45.30^{\mathrm{a}}$ & $44,20^{\mathrm{a}}$ & $43,10^{\mathrm{a}}$ & $33,30^{\mathrm{b}}$ & $33.13^{\mathrm{b}}$ \\
$\begin{array}{l}\text { Kadar HDL (High Density Lipoprotein) air susu } \\
\text { kambing (mg/dl) }\end{array}$ & $54,70^{\mathrm{a}}$ & $55,80^{\mathrm{a}}$ & $56,90^{\mathrm{a}}$ & $66,70^{\mathrm{b}}$ & $66,87^{\mathrm{b}}$ \\
\hline
\end{tabular}

Ket: Huruf superskrip yang berbeda pada baris yang sama menunjukkan adanya perbedaan yang sangat nyata $(\mathrm{P}<0,01)$. 
Selain itu penambahan sabun terproteksi dari minyak ikan tuna dan minyak ikan lemuru dapat menurunkan kandungan kolesterol susu kambing terlihat pada P3 dan P4, hal ini sependapat dengan Sutardi (1998) dalam Sudibya $d k k$. (2006, 2007 dan 2010) bahwa kadar kolesterol dalam daging sapi potong dan daging kambing serta air susu sapi perah dapat turun akibat transfer asam lemak omega-3, hal ini dapat dijelaskan bahwa asam lemak omega-3 berfungsi merangsang katabolisme kolesterol oleh HDL ke hati kembali menjadi asam empedu dan tidak diregenerasi lagi namun dikeluarkan bersama ekskreta, sehingga kandungan kolesterol dalam ekskreta meningkat akibat lebih lanjut kadar kolesterol yang terdeposisi di dalam air susu kambing berkurang. Selanjutnya P3 berbeda tidak nyata dengan $\mathrm{P} 4$, hal ini disebabkan oleh kandungan sabun terproteksi asam lemak tak jenuh antara minyak ikan lemuru dengan minyak ikan tuna yang relatif sama sehingga pengaruhnya nampak berbeda tidak nyata.

\section{Kadar LDL (Low Density Lipoprotein) Air Susu Kambing}

Kadar LDL (Low Density Lipoprotein) air susu kambing yang menunjukkan angka tertinggi pada perlakuan P0 yakni 45,30 mg/dl sedangkan angka yang terendah pada perlakuan P4 yakni 33,13 mg/dl dapat dilihat pada Tabel 3.

Hasil analisis statistik menunjukkan bahwa perlakuan suplementasi sabun asam lemak PUFA terproteksi yang mengandung $500 \mathrm{ppm}$ 1-karnitin berpengaruh sangat nyata $(\mathrm{P}<0,01)$ terhadap kadar LDL air susu kambing. Dari uji lanjut orthogonal kontras terlihat bahwa kadar LDL air susu kambing pada P0, P1 dan P2 berbeda sangat nyata dengan P3 dan P4. Selanjutnya P2 berbeda sangat nyata dengan P3 dan P4 serta P3 berbeda tidak nyata dengan $\mathrm{P} 4$.

Kadar LDL air susu kambing yang ditambah L-karnitin (P2) mengalami penurunan bila dibanding pada $\mathrm{P} 0$ dan $\mathrm{P} 1$ hal ini sejalan dengan pendapat Owen et al. (1996) yang menyatakan bahwa suplementasi L-karnitin dapat digunakan untuk menurunkan kadar LDL karena L-karnitin mampu menurunkan kandungan kolesterol dan LDL adalah bagian dari kolesterol.

Selain itu suplementasi sabun asam lemak PUFA terproteksi dapat menurunkan kandungan LDL air susu kambing, terbukti pada P3 dan P4, hal ini karena kedua minyak ikan tersebut mengandung asam lemak tak jenuh. Selanjutnya P3 berbeda tidak nyata dengan P4, hal ini disebabkan oleh kandungan asam lemak tak jenuh pada sabun terproteksi minyak ikan lemuru dengan minyak ikan tuna yang relatif sama sehingga pengaruhnya tidak nampak berbeda.

Selain itu suplementasi sabun minyak ikan terproteksi dapat menurunkan kandungan LDL daging domba, hal ini sependapat dengan Komari (1994) dan Layne et al., Sinclair (1996) serta Sudibya $d k k$. (2009) yang menyatakan bahwa penambahan ekstrak asam lemak tak jenuh mampu menurunkan kadar LDL pada hewan percobaan.

\section{Kadar HDL (High Density Lipoprotein) Air Susu Kambing}

Kadar HDL (High Density
Lipoprotein) air susu kambing yang
menunjukkan angka terendah pada perlakuan
P0 yakni $54,70 \mathrm{mg} / \mathrm{dl}$ sedangkan angka yang
tertinggi pada perlakuan P4 yakni 61,87
mg/dl.
$\quad$ Hasil analisis statistik menunjukkan
bahwa perlakuan suplementasi sabun asam lemak PUFA terproteksi yang mengandung 500 ppm L-karnitin berpengaruh sangat nyata $(\mathrm{P}<0,01)$ terhadap kadar HDL air susu kambing. Dari uji lanjut orthogonal kontras terlihat bahwa kadar HDL air susu kambing pada P0, P1 dan P2 berbeda sangat nyata dengan P3 dan P4. Selanjutnya P2 berbeda sangat nyata dengan P3 dan P4 serta P3 berbeda tidak nyata dengan P4. Namun P0 
berbeda tidak nyata dengan $\mathrm{P} 1$ dan $\mathrm{P} 2$ serta $\mathrm{P} 1$ juga berbeda tidak nyata dengan $\mathrm{P} 2$.

Kadar HDL air susu kambing yang ditambah L-karnitin (P2) mengalami peningkatan bila dibanding pada P0 dan P1 hal ini sejalan dengan pendapat Owen et al. terproteksi dapat menaikkan kandungan HDL air susu kambing, terbukti pada P3 dan P4, hal ini karena kedua minyak ikan tersebut mengandung asam lemak tak jenuh tinggi. Selanjutnya P3 berbeda tidak nyata dengan $\mathrm{P} 4$, hal ini disebabkan oleh kandungan asam lemak tak jenuh pada sabun terproteksi minyak ikan lemuru dengan minyak ikan tuna yang relatif sama sehingga pengaruhnya tidak nampak berbeda.

Selain itu suplementasi sabun minyak ikan terproteksi dapat meningkatkan kandungan HDL air susu kambing, hal ini sependapat dengan Komari (1994) dan Layne
(1996) yang menyatakan bahwa suplementasi L-karnitin dapat digunakan untuk menaikkan kadar HDL karena L-karnitin mampu menurunkan kandungan LDL. Selain itu suplementasi sabun asam lemak PUFA

et al., Sinclair (1996) serta Sudibya $d k k$. (2009) yang menyatakan bahwa penambahan ekstrak asam lemak tak jenuh mampu meningkatkan kadar HDL pada hewan percobaan.

\section{Kadar Asam lemak Omega-3 (Linolenat) dalam Air Susu Kambing}

Kadar asam lemak omega-3 yang tertinggi pada perlakuan P4 yakni $4,04 \%$ sedangkan yang terendah pada perlakuan P0 yakni $1,10 \%$. Selanjutnya dapat dilihat pada Tabel 4.

Tabel 4. Rataan Kadar Asam Lemak Omega-3 dan Omega-6 Pada Air Susu Kambing

\begin{tabular}{llllll}
\hline Peubah yang diukur & P0 & P1 & P2 & P3 & P4 \\
\hline Kadar asam lemak omega-3 (\%) & $1,10^{\mathrm{a}}$ & $1,25^{\mathrm{a}}$ & $1,60^{\mathrm{a}}$ & $3,90^{\mathrm{b}}$ & $4,04^{\mathrm{b}}$ \\
Kadar asam lemak omega-6 (\%) & $1,56^{\mathrm{a}}$ & $1,98^{\mathrm{a}}$ & $3,60^{\mathrm{a}}$ & $18,60^{\mathrm{b}}$ & $18,90^{\mathrm{b}}$ \\
\hline
\end{tabular}

Keterangan: Huruf superskrip yang berbeda pada baris yang sama menunjukkan adanya perbedaan yang sangat nyata $(\mathrm{P}<0,01)$.

Hasil analisis statistik menunjukkan bahwa perlakuan suplementasi sabun asam lemak PUFA terproteksi yang mengandung 500 ppm L-karnitin berpengaruh sangat nyata $(\mathrm{P}<0,01)$ terhadap kadar asam lemak omega-3 air susu kambing. Dari uji lanjut orthogonal kontras terlihat bahwa kadar asam lemak omega-3 air susu kambing pada P0, P1 dan P2 berbeda sangat nyata dengan P3 dan P4. Selanjutnya P2 berbeda sangat nyata dengan P3 dan P4 serta P3 berbeda tidak nyata dengan P4. Namun P0 berbeda tidak nyata dengan P1 dan P2 serta P1 juga berbeda tidak nyata dengan $\mathrm{P} 2$.

Kadar asam lemak omega-3 air susu kambing yang ditambah L-karnitin (P2) tidak mengalami peningkatan bila dibanding pada P0 dan P1 hal ini sejalan dengan pendapat Owen et al. (1996) yang menyatakan bahwa suplementasi L-karnitin tidak dapat digunakan untuk menaikkan kadar asam lemak omega-3.

Selain itu suplementasi sabun minyak ikan terproteksi dapat menaikkan kandungan asam lemak omega-3, hal ini dapat dijelaskan selain minyak sebagai sumber energi juga dapat 
sebagai sumber asam lemak tak jenuh sehingga mampu menaikkan kadar asam lemak omega-3 dalam air susu kambing. Hal ini sejalan dengan pendapat Suarez et al. (1996) yang menyatakan bahwa suplementasi omega-3 pada ransum berpengaruh terhadap konsentrasi asam lemak omega-3 pada jaringan tubuh. Selanjutnya bila dibandingkan penelitian Sudibya $d k k$. (2006 dan 2007) yang menyatakan bahwa kandungan asam lemak omega-3 pada daging sapi potong yang disuplementasi dengan minyak ikan lemuru sebesar 5,92\% dan pada daging kambing sebesar 5,96\%, maka pada penelitian ini nilainya diatas sedikit lebih tinggi namun masih dalam batas normal. Sampai saat ini yang menjadi pertimbangan para ahli biasanya nisbah antara asam lemak omega-3 dan omega-6.

\section{Kadar Asam lemak Omega-6 (Linoleat) dalam Air Susu Kambing}

Kadar asam lemak omega-6 yang tertinggi pada perlakuan P4 yakni 18,90\%, sedangkan yang terendah pada perlakuan $\mathrm{P} 0$ yakni $1,56 \%$. Selanjutnya dapat dilihat pada Tabel 4.

Hasil analisis statistik menunjukkan bahwa perlakuan suplementasi sabun asam lemak PUFA terproteksi yang mengandung 500 ppm L-karnitin berpengaruh sangat nyata $(\mathrm{P}<0,01)$ terhadap kadar asam lemak omega-6 air susu kambing. Dari uji lanjut orthogonal kontras terlihat bahwa kadar asam lemak omega-6 air susu kambing pada P0, P1 dan P2 berbeda sangat nyata dengan P3 dan P4. Selanjutnya P2 berbeda sangat nyata dengan P3 dan P4 serta P3 berbeda tidak nyata dengan P4.

Kadar asam lemak omega-6 air susu kambing yang ditambah L-karnitin (P2) tidak mengalami peningkatan bila dibanding pada P0 dan P1 hal ini sejalan dengan pendapat Owen et al. (1996) yang menyatakan bahwa suplementasi L-karnitin tidak dapat digunakan untuk menaikkan kadar asam lemak omega-6.
Selain itu suplementasi sabun minyak ikan terproteksi dapat menaikkan kandungan asam lemak omega-6, hal ini dapat dijelaskan selain minyak sebagai sumber energi juga dapat sebagai sumber asam lemak tak jenuh sehingga mampu menaikkan kadar asam lemak omega-6 dalam air susu kambing. Hal ini sejalan dengan pendapat Suarez et al. (1996) yang menyatakan bahwa suplementasi omega-3 pada ransum berpengaruh terhadap konsentrasi asam lemak omega-6 pada jaringan tubuh. Selanjutnya bila dibandingkan penelitian Sudibya $d k k$. (2006 dan 2007) yang menyatakan bahwa kandungan asam lemak omega-6 pada daging sapi potong yang disuplementasi dengan minyak ikan lemuru sebesar 18,92\% dan pada daging kambing sebesar 18,96\%, maka pada penelitian ini nilainya diatas sedikit lebih rendah namun masih dalam batas normal.

Sampai saat ini yang menjadi pertimbangan para ahli biasanya nisbah antara asam lemak omega-3 dan omega-6. Pada penelitian ini ternyata mempunyai perbandingan 4,04\% (1) dengan 18,90\% $(5,0)$. Hal ini didukung oleh Newton (1996) bahwa rekomendasi dari WHO dan FAO mempunyai nisbah omega-3 dan omega-6 sebesar 1:5.

\section{KESIMPULAN DAN IMPLIKASI}

\section{Kesimpulan}

1. Suplementasi asam lemak PUFA terproteksi hingga level 5\% yang mengandung 500 ppm L-karnitin dalam ransum limbah pasar organik terfermentasi mampu menurunkan kadar kolesterol air susu dari $0,482 \%$ menjadi $0,420 \%$ dan kadar LDL (Low Density Lipoprotein) air susu dari 45,30 mg/dl hingga 33,13 mg/dl. Selanjutnya mampu meningkatkan kadar HDL (High Density Lipoprotein) air susu kambing dari 54,70 menjadi 66,87 mg/dl.

2. Suplementasi asam lemak PUFA terproteksi hingga level 5\% yang mengandung L-karnitin dalam ransum 
limbah pasar organik terfermentasi mampu meningkatkan kadar asam lemak omega-3 air susu dari $1,10 \%$ menjadi $4,04 \%$ dan kadar asam lemak omega-6 dari 1,46\% hingga $18,80 \%$.

\section{Implikasi}

Suplementasi L-karnitin hingga level 500 ppm dan asam lemak PUFA terproteksi hingga level $5 \%$ dapat dilakukan dalam ransum kambing yang mengandung limbah pasar organik terfermentasi.

\section{DAFTAR PUSTAKA}

Adnan, M. 1980. Lipid Properties and Stability of Partially Defatted Peanuts. Disertation Doctor. University of Illinois at Urbana. Champaign.

AOAC, 1990. Official Methods of Analysis of the Association of Official Analytical Chemists. Association of Official Analytical Chemist. Washington, D. C. Apriyantono, A., D. Fardiaz, N.L. Puspitasari, Sedarnawati dan S. Budiyanto. 1989. Petunjuk Laboratorium Analisis Pangan. Pusat Antar Universitas Pangan dan Gizi IPB Bogor.

Assman, G. 1982. Lipid metabolism and Atherosclerosis Schattaver. Verlag Stuffgart.

Beltran, A. and A. Moral. 1991. Changes im Fatty Acid Composition of Fresh and Frozen Sardine (Sardina pilchardus W) During Smoking. Food Chemistry. 42: 99-109.

Bray, D.L. and G.M. Briggs. 1980. Carnitine in: R. Goodhart and M. Shills eds. Modern Nutritions in Health and Deseases. Lea and Febiger. Philadelphia. Pp.291-293.

Cherian, G. and J.S. Sim. 1992. Preferential Accumulation of $n-3$ fatty acids in the brain of chicks from eggs enriched with n-3 fatty acids. Poult.Sci.71: 1658-1668.
Chillard, Y. 1993. Dietary Fat and Adipose Tissue Metabolism in Ruminant, Pigs and Rodents: a Review. J. Dairy Sci. 76.3897-3931.

Czerkawski, J.W. and J.C. Clapperton. 1984. Fats and Energy-yielding Coumpounds in The Ruminant Diet. In Fat in Animal Nutrition. Ed. J Wiseman Butterworths, Boston, MA. pp: 249263.

Cry, D.M., S.G. Edan, C.M. Brini and G.C. Trenblay, 1991. On the mechanism of inhibition of gluconeogenesis and ureagenesis by sodium benzoate. Biochem Pharmacol. 42: 645.

Direktorat Jenderal Perikanan. 1982. Direktorat Jenderal Perikanan. Departemen Pertanian. Jakarta.

Feller, A.G. and D. Rudman. 1988. Role of Carnitine in Human Nutrition. J. Nutr. 118: 541-547.

Hunter, J.E. 1987. PUFA and eicosanoid research. J. Am. Oil. Chem. Soc. 64(8): 1088-1092.

Igene, J.O. and A.M. Pearson. 1979. Role of Phospholipids and Trigliserides in Warmed Over Flavour Developmentt in Meat System. J. Food Sci. 44: 1285.

Kempen, T.A., T.G. Van and J. Odle. 1995. Carnitine effects octanoat oxidation to carbondioxide and dicarboxylic acids in colostrum-deprived piglets: In vivo analysis of mechanisms involved based on $\mathrm{CoA}$ and carnitine ester profiles. J. Nutr. 125: 238-250.

Kinsella, J.E.B. Lokesh and R.A. Stone. 1990. Dietary n-3 polyunsaturated fatty acids and amelioration of cardiovascular disease posible mechanism. Am.J.Clin.Nutr. 2: 28.

Kleiner, I.S. and L.B. Dotti, 1962. Laboratory Instruction in Biochemistry sixth edition. The C.V. Mosby Company. New York.

Lin,D.S. and W.E. Connor. 1990. Are the n-3 fatty acids from dietary fish oil deposited in the triglyceride storoges 
of adipose tissue. Am. J. Clin. Nutr.51: 535-539.

Montgomery, M. Dryer, R.L. Conway, T.W and A.A. Speator. 1993. Biokimia: Suatu Pendekatan Berorientasi Kasus. Jilid 2. Gajah Mada University Press. Yogyakarta. Hal. 179, 726.

Nawar, W.W. 1985. Lipids. Ed: Fennema. Food Chemistry. Marcell Dekker. Inc. New York.

Newton, I.S. 1996. Food enricment with longchain n-3 PUFA. INFORM 7: 169171.

Owen, K.Q., T.L. Weeden, J.L. Nelssen, S.A. Blum and R.D. Goodband. 1993. The effect of L-carnitine addition on performance and carcass characteristic ofof growing-finishing swine. J. Anim. Sci: 62.

Owen, J.L. Nelssen, R.D. Goodband, T.L. Weeden and S.A. Blum. 1996. Effect of L-carnitine and soybean oil growth performance and body composition of early weaned pigs. J. Anim. Sci. 74:1612-1619.

Owen, L.H. Kim and C.S. Kim. 1997. The role of L-carnitine in swine nutrition and metabolism. Kor. J.Anim. Nutr. Feed. 21 (1): 41-58.

Sardesai, V.M. 1992. Nutritional role of poly unsaturated fatty acids. J.Nutr.Biochem. 3: 154-166.

Septiana, A.T, P. Yuwono, T. Setyowati dan T. Widyastuti. 1997. Pengaruh Pembakaran Daging Kambing, Ayam dan Itik pada Pembuatan Sate terhadap Pembentukan Produk Oksidasi Lemak. Laporan Hasil Penelitian. Fakultas Peternakan Universitas Jenderal Soedirman. Purwokerto.

Simopoulos, A.P. 1989. Summary of the NATO advanced research workshop on dietary $\omega-3$ and $\omega-6$ fatty acids: Bilogical effects and nutritional essentially. Am.inst.of nutr. 22: 521527.
Soeparno. 1994. Ilmu dan Teknologi Daging. Gajah Mada University Press. Yogyakarta.

Steel, R.G.D. and J.H. Torrie. 1980. Principles and Prosedures of Statistic. Mc Graw-Hill Inc. New York. Toronto. London.

Suarez, A.M.D.C. Ramires, M.J. Faus and A. Gil. 1996. Dietary long-chain polyunsaturated fatty acids influence tissue fatty acid composition in rats at weaning. J.Nutr. 126: 887-897.

Sudibya. 1998. Manipulasi Kadar Kolesterol dan Asam Lemak Omega-3 Telur Ayam Melalui Penggunaan Kepala Udang dan Minyak Ikan Lemuru. Disertasi Program Pasca Sarjana IPB. Bogor.

Sudibya, Suparwi, T.R. Sutardi, H. Soeprapto dan Y. Dwi. 2003. Produksi Daging Sapi Rendah Kolesterol yang Kaya Asam Lemak Omega-3 dan Pupuk Organik dengan EM-4 Di Kelompok Martini Indah di Kabupaten Purwodadi. Proyek Pengembangan dan Peningkatan Kemampuan Teknologi Proyek Program Iptekda VI. LIPI. Jakarta. Lembaga Penelitian Univesitas Jenderal Soedirman Purwokerto.

Sudibya, D. Prabowo dan Hartoko. 2004. Suplementasi enzim selulase dan ekstrak asam lemak tak jenuh dalam ransum dasar terhadap kualitas dan kuantitas asam lemak tak jenuh telur. Journal Ilmiah. Lembaga Penelitian Unsoed. No.2 Vol. XXX. Edisi Juli Tahun 2004.

Sudibya. 2005. Suplementasi Prekursor Karnitin dan L-Karnitin Serta Minyak Ikan Tuna Terhadap Kadar Kolesterol dan Asam Lemak Tak Jenuh Telur Itik Tegal. Fakultas Peternakan Unsoed Purwokerto.

Sudibya, S. Triatmojo dan H. Pratiknyo. 2006. Perbaikan Kualitas daging Sapi Melalui Transfer Omega-3 Terkapsul 
dan Tape Bekatul Serta Produksi Pupuk Organik dengan Starter Gama95 Di Kelompok Ternak Sapi Potong "Sidamaju" di Kabupaten Bantul. Proyek Pengembangan dan Peningkatan Kemampuan Teknologi Proyek Program Iptekda IX. LIPI. Jakarta. Lembaga Pengabdian Kepada Madyarakat Univesitas Jenderal Soedirman Purwokerto.

Sudibya, T. Widyastuti dan S.S. Santoso. 2007. Transfer Omega-3 Melalui Kapsulisasi dan L-Karnitin Pengaruhnya Terhadap Komposisi Kimia Daging Kambing. Laporan Hasil Penelitian Hibah Bersaing IX. Fakultas Peternakan Universitas Jenderal Soedirman. Purwokerto.

Sudibya, P. Martatmo dan Sudiyono. 2009. Transfer Omega-3 Terproteksi dan Minyak Kedele dalam Ransum Bekatul Terfermentasi Terhadap Kadar Asam Linolenat, Linoleat dan Arakhidonat Air Susu Sapi Perah. Laporan Penelitian Hibah SINTA Prodi Peternakan Fakultas Pertanian Universitas Sebelas Maret. Surakarta.

Sudibya, P. Martatmo dan Darsono. 2009. Transfer Omega-3 Terproteksi dan LKarnitin Dalam Ransum Onggok Terfermentasi Terhadap Komposisi Kimiawi Daging Domba. Laporan Penelitian Hibah Stranas. Prodi Peternakan Fakultas Pertanian Universitas Sebelas Maret. Surakarta.

Sudibya, P. Martatmo, A. Ratriyanto dan Darsono. 2010. Transfer Omega-3 Terproteksi dan L-Karnitin dalam Ransum Limbah Pasar Terfermentasi Terhadap Komposisi Kimiawi Daging Sapi Simental. Laporan Penelitian
Hibah Kompetensi Prodi Peternakan Fakultas Pertanian Universitas Sebelas Maret. Surakarta.

Sudibya and S.H. Purnomo. 2013. Transfer of pufa Fatty Acid Protected and Carnitin Precursor on the ration of chemical composition of milk dairy goat. Open Journal of Animal Sciences. Vol 3 Number 3. April 2013. Page 222-227.

Sudibya and S.H. Purnomo. 2013. Transfer of Omega-3 Fatty Acid Protected and Rice Bran Fermented in The Ration of Chemica Composition of milk Dairy Cow. Jurnal Media Peternakan. Animal Science and Technology. Vol 33 Number 3. page. 222-229.

Sustriawan, B., R. Naufalin dan N. Aini. 2002. Mikroenkasulasi Konsentrat Asam lemak Omega-3 dari Minyak Ikan Tuna. Laporan Penelitian. Fakultas Pertanian Jurusan Teknologi Pertanian. Lembaga Penelitian UNSOED.

Tranggono dan S. Setiaji. 1986. Kimia Lipids. Pusat Antar Universitas Pangan dan Gizi. UGM. Yogyakarta.

Widiyastuti, T. C.H. Prayitno dan Sudibya. 2005. Pemanfaatan Kepala udang dan Suplementasi L-Carnitin Pada pakan Itik Lokal Yang mengandung Daun Lamtoro. Program Semi Que V Tahun II. Fakultas Peternakan. Laporan Penelitian Program Studi Nutrisi Ternak.

Wyatt, C.L. and T.N. Goodman. 1993. Effect of L-Carnitine and Dietary Lysine and Fat Levels On Grwoh Performance and Body Lipid Content in Young Broilers. PoulSci. 72: 200. 
